\title{
UPAYA MENINGKATKAN MOTIVASI DAN HASIL BELAJAR BAHASA INDONESIA MENENTUKAN KALIMAT KESIMPULAN (IDE POKOK) DARI BERBAGAI POLA PARAGRAF INDUKSI-DEDUKSI DENGAN TEKNIK MEMBACA INTENSIF SISWA KELAS XII IPS-1 SMAN 1 HINAI KABUPATEN LANGKAT TAHUN PELAJARAN 2018/2019
}

\author{
Drs.Norben \\ SMA Negeri 1 Hinai, Langkat, Sumatera Utara \\ Jl.Olah raga Desa Batu Malenggang Hinai
}

\begin{abstract}
ABSTRAK
Permasalahan pembelajaran yang muncul terutama di kelas XII IPS-1 SMAN 1 Hinai tempat peneliti mengajar adalah rendahnya motivasi belajar yang berimplikasi pada rendahnya hasil belajar siswa baik secara individu maupun klasikal. Untuk itu diperlukan upaya ilmiah untuk dapat memecahkan permasalahan tersebut antara lain dengan melakukan Penelitian Tindakan Kelas. Penelitian dilaksanakan di kelas XII IPS-1 SMAN 1 Hinai Tahun Pelajaran 2018/2019, sebanyak dua siklus. Setiap siklus kegiatan penelitian meliputi perencanaan, tindakan, pengamatan dan refleksi. Subyek penelitian adalah 33 siswa, metode pengumpulan data yang digunakan adalah pengamatan dan tes hasil belajar setiap akhir siklus, indikator keberhasilan secara individual yaitu mencapai nilai 80 dan klasikal yang mencapai nilai 80 sebanyak $70 \%$ lebih dikatakan berhasil. Hasil penelitian membuktikan bahwa penerapan pendekatan teknik membaca intensif pada materi menemukan pikiran pokok teks bacaan dapat meningkatkan Nilai rata-rata kelas semakin meningkat dari 72,73 pada studi awal, menjadi 78,33 pada siklus I, dan pada siklus II menjadi 82,27 dengan tingkat ketuntasan belajar dari 7 siswa atau $21,21 \%$ menjadi 20 siswa atau 60,61\% dan 31 siswa atau 93,94\% pada siklus kedua. Adapun peningkatan motivasi belajar juga semakin membaik, pada studi awal sebesar 24,24\% (8 siswa) menjadi 21 siswa $(63,64 \%)$ pada siklus I, dan 93,94\% (31 siswa) pada siklus II. Kesimpulannya adalah penerapan teknik membaca intensif dapat meningkatkan motivasi dan hasil belajar siswa XII IPS-1 SMAN 1 Hinai Tahun Pelajaran 2018/2019.
\end{abstract}

Kata Kunci : membaca intensif, ide pokok, motivasi, hasil belajar.

\section{PENDAHULUAN}

Peraturan Menteri Pendidikan Nasional Nomor 22 Tahun 2006 tentang Standar Isi, menjelaskan bahwa dengan adanya mata pelajaran bahasa Indonesia, siswa diharapkan memiliki kemampuan: (1) berkomunikasi secara efektif dan efisien sesuai dengan etika yang berlaku; (2) menghargai dan bangga mengguna kan bahasa Indonesia; (3) memahami bahasa Indonesia dan menggunakannya dengan tepat dan menggunakan bahasa Indonesia untuk meningkatkan kemampuan intelektual, serta kematangan emosional dan sosial; (5) menikmati dan memanfaatkan karya sastra untuk memperluas wawasan, memperhalus budi pekerti, serta meningkatkan pengetahuan dan kemampuan berbahasa; dan (6) menghargai dan membanggakan sastra Indonesia.

Guru sebagai tenaga pendidik atau pengajar yang telah dibekali seperangkat kemampuan yang dibutuhkan dalam 


\section{Jurnal Serunai Ilmu Pendidikan Vol.5, No.2, Desember 2019 e-ISSN 2621 - 2676}

pembelajaran, tentu harus berperan sebagai demonstrator, pengelola kelas, mediator, motivator dan fasilitator yang optimal sehingga pembelajaran yang dilaksanakan akan mencapai tujuan yang ditetapkan. Kenyataan dilapangan menunjukkan bahwa keterampilan dan kemampuan menulis siswa di sekolah dasar masih belum memuaskan. Hal ini disebabkan oleh adanya beberapa hambatan, baik yang bersifat internal maupun eksternal. Hambatanhambatan tersebut diantaranya adalah hambatan psikologis maupun metodologis. Hambatan psikologis dapat dilihat dari sikap sikap kebanyakan peserta didik yang menganggap pembelajaran menulis sebagai suatu beban dan sulit. Sementara hambatan metodologis dapat dilihat dari penggunaan metode pembelajaran yang cenderung kurang proporsional, dimana antara teori dan praktek masih belum seimbang. Selain rendahnya minat siswa terhadap pembelajaran membaca, masalah tersebut juga termasuk kurangnya kreativitas guru untuk mengembangkan teknik pembelajaran membaca. Permasalahan pembelajaran yang muncul terutama di kelas XII IPS-1 SMAN 1 Hinai Kabupaten Langkat, di tempat peneliti mengajar adalah rendahnya motivasi belajar yang berimplikasi pada rendahnya hasil belajar siswa baik secara individu maupun klasikal.
Tujuan pengajaran harus tepat pada sasaran. Banyak faktor yangmendukung keberhasilan pengajaran, diantaranya guru, siswa, sarana danprasarana, metode dan teknik pembelajaran. Di antara faktor-faktor pendukungkeberhasilan pengajaran tersebut yang paling banyak menentukan keberhasilan pengajaran adalah teknik, atau cara. Oleh karena itu, guru harus dapat mengkombinasikan teknik pengajaransesuai dengan situasi. Hal ini dilakukan supaya siswa tidak bosan dan PBM tidak terkesan monoton. Walaupun peranan guru sangat dominan dalam pembelajaran tetapi keberhasilan dalam melaksanakan suatu pelajaran sebagian besar ditentukan oleh pilihan bahan dan pemakaian metode yang tepat.

\section{METODE PENELITIAN}

Dalam penelitian ini penulis mengambil lokasi di kelas XII IPS-1 SMAN 1 Hinai Kabupaten Langkat Tahun Pelajaran 2018/2019. Waktu yang dibutuhkan dalam pelaksanaan kegiatan penelitina ini adalah 3 bulan, yaitu dari bulan Januari sampai dengan Maret 2019 dengan perhitungan waktu kurang lebih 10 minggu. Subjek penelitian dalam penelitian ini adalah siswa kelas XII IPS-1 SMAN 1 Hinai Kabupaten Langkat Tahun Pelajaran 2018/2019 dengan jumlah siswa sebanyak 33 siswa. 


\section{Jurnal Serunai Ilmu Pendidikan \\ Vol.5, No.2, Desember 2019 \\ e-ISSN 2621 - 2676}

Tehnik Pengumpulan data dalam penelitian ini menggunakan observasi, wawancara, lembar kerja siswa, dan tes. Pelaksanaan penelitian tindakan kelas ini dilakukan dalam dua siklus, maka tes perbuatan juga dilakukan dua kali, yaitu pada akhir siklus I dan akhir siklus II, Perangkat tes terdiri dari butir soal, kunci jawaban, kriteria dan hasil tes terlampir. Sedangkan data peningkatan motivasi belajar siswa menggunakan lembar observasi.

Secara keseluruhan dalam setiap siklus terdapat empat tahap yang harus ditempuh, yaitu:

1. Perencanaan

a. Membuat rencana pengajaran beserta skenario tindakan yang akan dilaksanakan berdasarkan identifikasi permasalah. Tahapan perencanaan ini mencakup pemilihan bahan, media, cara dan alat evaluasi;

b. Menentukan teknik membaca intensif yang akan digunakan dalam pembelajaran.

c. Menyusun alat observasi untuk melihat aktivitas siswa dan guru dalam pembelajaran

d. Merencanakan diskusi dengan mitra peneliti berdasarkan observasi terhadap aktivitas guru dan siswa.

2. Tindakan

Pelaksanaan tindakan dalam pembelajaran menemukan pikiran pokok teks bacaan dengan teknik membaca intensif akan dilaksanakan sebanyak 2 siklus. Di mana masing-masing siklus akan dijelaskan sebagai berikut.

\section{a. SIKLUS I}

Peneliti memberikan arahan, motivasi dan rangsangan kepada semua personil yang terkait dalam pelaksanaan tindakan dengan kegiatan sebagai berikut:

1) Merumuskan masalah yang timbul.

2) Merancang tindakan yang akan dilakukan.

3) Membuat rencana pelaksanaan pembelajaran berdasarkan pendekatan yang akan diterapkan dalam menentukan kalimat kesimpulan (ide pokok) dari berbagai pola paragraf induksi, deduksi dengan teknik membaca intensif

4) Melakukan observasi yang dilakukan oleh tim peneliti (observer) dan dilaksanakan dalam pelaksanaan tindakan dalam rangka pengumpulan data.

5) Bersama dengan observer menganalisis dan merefleksi pelaksanaan hasil tindakan siklus 1. Pelaksanaan analisis siklus 1 dilakukan untuk memperoleh gambaran secara kualitatif dari proses pelaksanaan tindakan dan observasi, kemudian dijadikan perencanaan untuk siklus selanjutnya.

\section{b. SIKLUS II}

Pada siklus 2 ini, pelaksanaan tindakan yang dilakukan sesuai dengan perencanaan perbaikan dari hasil analisis pada 
siklus 1. Peneliti harus berusaha memahami dan mengingat apa yang sudah dirumuskan dalam rancangan. Kegiatan yang dilakukan pada siklus 2 ini diantaranya sebagai berikut:

1) Merancang tindakan yang dilakukan dengan menekankan kepada hal- hal yang harus diperbaiki berdasarkan hasil refleksi pada siklus 1 .

2) Membuat rencana pelaksanaan pembelajaran berdasarkan pendekatan pembelajaran yang akan diterapkan dalam menemukan pikiran pokok naskah bacaan.

3) Melakukan observasi yang dilakukan oleh tim peneliti (observer) dan dilaksanakan dalam pelaksanaan tindakan dalam rangka pengumpulan data.

4) Bersama dengan observer menganalisis dan merefleksi pelaksanaan hasil tindakan siklus 2 . Pelaksanaan analisis siklus 2 dilakukan untuk memperoleh gambaran secara kualitatif dan kuantitatif dari proses pelaksanaan tindakan dan observasi, kemudian dijadikan perencanaan tindakan dalam siklus selanjutnya.

\section{Pengamatan}

Peran peneliti dalam penelitian adalah sebagai guru, sedangkan pengamatan dilakukan oleh observer. Pengamatan dilakukan dengan menggunakan instrumen pedoman observasi yang telah disusun, untuk memperoleh seperangkat data tentang pelaksanaan tindakan, kendala-kendala yang dihadapi, serta kesempatan dan peluang yang ada berkaitan dengan pembelajaran menentukan kalimat kesimpulan (ide pokok) dari berbagai pola paragraf induksi, deduksi. Pengamatan dilakukan dari siklus 1 sampai siklus 2 secara terus menerus. Hasil pengamatan ini kemudian didiskusikan antara peneliti dan observer, sehingga menghasilkan refleksi yang berpengaruh pada perencanaan siklus berikutnya.

\section{Refleksi}

Refleksi merupakan bagian yang penting untuk memahami proses dan hasil perubahan yang terjadi dari pelaksanaan tindakan yang telah dilakukan. Peneliti dan observer mendiskusikan hasil pengamatan kegiatan tindakan yang telah dilakukan selama penelitian berlangsung. Sehingga pada siklus berikutnya merupakan revisi dan daur ulang dari siklus sebelumnya yang dapat dijadikan sebagai perenungan untuk melakukan pembelajaran yang lebih baik lagi.

Adapun kriteria keberhasilan siswa setelah melalui proses perbaikan pembelajaran, yaitu sebagai berikut : (1) Seluruh siswa mengalami proses belajar yang bermakna atau berbeda daripada sebelumnya, dengan ketentuan siswa 
mampu menguasai materi minimal $70 \%$ atau mendapat nilai 80 sesuai dengan KKM yang telah ditentukan; (2) Proses perbaikan pembelajaran dinyatakan berhasil apabila $85 \%$ dari jumlah siswa tuntas belajar; (3) Proses perbaikan pembelajaran dinyatakan berhasil apabila $85 \%$ dari jumlah siswa menunjukkan peningkatan motivasi dan hasil belajar selama proses pembelajaran berlangsung.

\section{HASIL PENELITIAN DAN PEMBAHASAN}

\section{Hasil Penelitian}

Data awal diperoleh dari hasil temuan pada saat dilakukannya proses belajar mengajar sebelum penelitian dilaksanakan. Permasalahan pada pembelajaran bahasa Indonesia materi menemukan pokok pikiran teks bacaan siswa kelas XII IPS-1 SMAN 1 Hinai tersebut, yaitu masih rendah. Nilai rata-rata pada kondisi awal adalah 72,73, sedangkan nilai KKM adalah 80 . Dari hasil mengajar, wawancara, dan tes dapat diperoleh gambaran bahwa kemampuan siswa dalam menemukan pokok pikiran teks bacaan masih tergolong rendah. Masih banyak siswa yang mengalami kesulitan dalam kompetensi dasar menentukan kalimat kesimpulan (ide pokok) dari berbagai pola paragraf induksi, deduksi. Kesulitan tersebut salah satunya karena guru kurang memberi waktu intensif kepada siswa untuk belajar membuat karangan. Ini disebabkan karena kurangnya waktu guru untuk mencoba memberikan pelajaran menemukan pokok pikiran teks bacaan, hal ini dikarenakan guru mengejar target untuk menyelesaikan materi pelajaran yang belum disampaikan. Selain itu juga, guru jarang menggunakan media dan metode pembelajaran yang kurang variatif terhadap pelajaran menemukan pokok pikiran teks bacaan.

Adapun penjelasan mengenai tingkat motivasi belajar siswa pada pembelajaran bahasa Indonesia kompetensi dasar menentukan kalimat kesimpulan (ide pokok) dari berbagai pola paragraf induksi, deduksi pada kondisi awal sebagaimana dijelaskan pada tabel di bawah ini.

Tabel 1. Hasil Observasi Motivasi Belajar Siswa pada Kondisi Awal

\begin{tabular}{ccccc}
\hline No & Kriteria & Jlh & Persentase & Ket \\
\hline 1 & Sangat Baik & 0 & 0,00 & T \\
\hline 2 & Baik & 0 & 0,00 & T \\
\hline 3 & Cukup & 8 & 24,24 & T \\
\hline 4 & Kurang & 8 & 24,24 & BT \\
\hline 5 & Sangkat Kurang & 17 & 51,52 & BT \\
\hline
\end{tabular}

Berdasarkan hasil tes formatif dan hasil pengamatan terhadap motivasi belajar kondisi awal serta berbagai hambatan-hambatan yang muncul, maka peneliti bersama guru kelas yang diteliti, melakukan kolaborasi untuk 
mengatasi hambatan dan kesulitan yang ditemukan, peneliti bersama guru kelas yang bertindak sebagai observer, menyusun dan melaksanakan serangkaian perencanaan tindakan guna mengatasi hambatan-hambatan tersebut, yang diakhiri pada sebuah kegiatan analisis atau refleksi.

Pelaksanaan tindakan kelas disesuaikan dengan rencana pembelajaran yang telah dirumuskan sebelumnya. Pelaksanaan tindakan penelitian kelas ini menekankan pada penggunaan teknik membaca intensif. untuk meningkatkan motivasi dan hasil belajar siswa yang diupayakan dan dikondisikan berdasarkan tahapan-tahapan yang telah dipersiapkan sebelumnya dalam tahap perencanaan dengan mengimplementasikan rencana tersebut yang telah dirumuskan oleh peneliti.

\section{Siklus Pertama}

Pada siklus pertama ini dalam tahap pelaksanaan sudah menunjukkan adanya peningkatan hasil belajar siswa. Hal tersebut dapat dilihat pada tabel berikut ini :

Tabel 2.Rekapitulasi Nilai Tes Formatif Pembelajaran Bahasa Indonesia Pada Siklus I

\begin{tabular}{|l|c|c|c|}
\hline \multirow{2}{*}{} & \multirow{2}{*}{ Nilai } & \multicolumn{2}{|c|}{ Kriteria Ketuntasan } \\
\cline { 3 - 4 } & & Tuntas & Belum Tuntas \\
\hline Jumlah & 2585 & 20 & 13 \\
\hline Nilai Tertinggi & 85 & - & - \\
\hline Nilai Terrendah & 70 & - & - \\
\hline
\end{tabular}

\begin{tabular}{|l|c|c|c|}
\hline Nilai Rata-rata & 78,33 & - & - \\
\hline $\begin{array}{l}\text { Persentase } \\
\text { Ketuntasan }\end{array}$ & - & 60,61 & 39,39 \\
\hline
\end{tabular}

Dari penjelasan sebagaimana tersebut di atas dapat disimpulkan bahwa hasil nilai tes formatif mengalami peningkatan dari kondisi awal, karena pada sebelum perbaikan siswa tuntas 7 siswa $(21,21 \%)$ meningkat menjadi 20 siswa $(60,61 \%)$ atau meningkat sebanyak 13 siswa $(39,39 \%)$.

Hasil observasi yang dilakukan terhadap peningkatan motivasi belajar siswa menunjukkan bahwa belum semua siswa dapat memahami konsep pembelajaran karena kurangnya pemahaman serta motivasi siswa terhadap materi pembelajaran yang disampaikan.

Tabel 3. Rekapitulasi Hasil Observasi Peningkatan Motivasi Siswa Pembelajaran Bahasa Indonesia Materi menemukan pokok pikiran teks bacaan Pada Siklus I

\begin{tabular}{clccc}
\hline No & $\begin{array}{c}\text { Rentang } \\
\text { Nilai }\end{array}$ & Jumlah & Persentase & Ket \\
\hline 1 & Sangat Baik & 6 & 18,18 & T \\
\hline 2 & Baik & 8 & 24,24 & T \\
\hline 3 & Cukup & 7 & 21,21 & T \\
\hline 4 & Kurang & 11 & 33,33 & BT \\
\hline & Sangat & & & \\
5 & Kurang & 1 & 3,03 & BT \\
\hline
\end{tabular}

Dari tabel di atas dapat disimpulkan bahwa dari 33 siswa terdapat 21 orang yang tuntas belajarnya $(63,64 \%)$ dilihat dari motivasi 
belajarnya, sedangkan 12 siswa $(36,36 \%)$ belum tuntas dilihat dari motivasi belajarnya. Melihat hasil di atas maka peneliti bersama-sama dengan observer sepakat untuk melaksanakan perbaikan pembelajaran pada siklus II dengan harapan pada siklus II motivasi belajar siswa dapat mencapai perolehan di atas $85 \%$ sesuai dengan kriteria keberhasilan yang telah ditetapkan.

Dari kenyataan temuan pada saat pelaksanaan siklus pertama, maka peneliti bersama-sama dengan observer memutuskan untuk mengadakan perbaikan pada siklus kedua dengan menerapkan : 1) Menfokuskan pada kegiatan kelompok pada sesi membaca intensif; 2) Siswa menentukan sendiri kelompoknya berdasarkan faktor-faktor kedekatan antar anggota dalam kelompoknya, misalnya kedekatan pertemanan dan kedekatan lokasi tempat tinggal; 3) Keanggotaan siswa tiap kelompok kerja semakin diperkecil sehingga diharapkan dapat meningkatkan keefektifan pembelajaran; 4) Memperbanyak fasilitas referensi buku sumber untuk mengembangkan materi pembelajaran misalnya dengan meminjam buku-buku yang relevan dengan materi pembelajaran di perpustakaan sekolah dan mempersilahkan siswa untuk bebas memilih sendiri buku-buku tersebut sesuai dengan bacaan yang dikuasainya.

\section{Siklus Kedua}

Pada siklus kedua ini dalam tahap pelaksanaan sudah menunjukkan adanya peningkatan hasil belajar siswa. Hal tersebut dapat dilihat pada tabel berikut ini :

Tabel 4. Rekapitulasi Nilai Tes Formatif Pembelajaran Bahasa Indonesia pada Siklus II

\begin{tabular}{|l|c|c|c|}
\hline \multirow{2}{*}{} & \multirow{2}{*}{ Nilai } & \multicolumn{2}{|c|}{ Kriteria Ketuntasan } \\
\cline { 3 - 4 } & 2715 & Tuntas & Belum Tuntas \\
\hline Jumlah & 90 & - & 2 \\
\hline $\begin{array}{l}\text { Nilai } \\
\text { Tertinggi }\end{array}$ & 75 & - & - \\
\hline $\begin{array}{l}\text { Nilai } \\
\text { Terrendah }\end{array}$ & 82,27 & - & - \\
\hline $\begin{array}{l}\text { Nilai Rata- } \\
\text { rata }\end{array}$ & - & 93,94 & 6,06 \\
\hline $\begin{array}{l}\text { Persentase } \\
\text { Ketuntasan }\end{array}$ & - & \\
\hline
\end{tabular}

Dari penjelasan sebagaimana tersebut di atas dapat disimpulkan bahwa hasil nilai tes formatif mengalami peningkatan dari siklus I, karena pada siklus I siswa tuntas 20 siswa $(61,61 \%)$ meningkat menjadi 31 siswa $(93,94 \%)$ atau meningkat sebanyak 11 siswa $(33,33 \%)$.

Hasil observasi menunjukkan bahwa pelaksanaan pembelajaran berjalan dengan baik, penguasaan konsep dan materi pembelajaran siswa sudah maksimal. Hal ini dibuktikan dengan nilai tes formatif dan peningkatan motivasi belajar siswa.

Tabel 5. Rekapitulasi Hasil Observasi Peningkatan Motivasi Siswa Pembelajaran Bahasa Indonesia Materi menemukan pokok pikiran teks bacaan Pada Siklus II 


\begin{tabular}{|c|l|c|c|c|}
\hline No & $\begin{array}{c}\text { Rentang } \\
\text { Nilai }\end{array}$ & Jlh & Persentase & Ket \\
\hline & Sangat & & & \\
1 & Baik & 14 & 42,42 & T \\
\hline 2 & Baik & 16 & 48,48 & T \\
\hline 3 & Cukup & 1 & 3,03 & T \\
\hline 4 & Kurang & 2 & 6,06 & BT \\
\hline & Sangat & & & \\
5 & Kurang & 0 & 0,00 & BT \\
\hline
\end{tabular}

Dari tabel di atas dapat disimpulkan bahwa dari 33 siswa terdapat 31 orang yang tuntas belajarnya $(93,94 \%)$ dilihat dari motivasi belajarnya. Melihat hasil di atas maka peneliti bersama-sama dengan observer menyimpulkan bahwa hasil pengamatan terhadap peningkatan motivasi belajar sudah mencapai angka di atas $85 \%$, sehingga proses perbaikan pembelajaran dinyatakan berhasil dan tuntas pada siklus II. Hampir semua tujuan telah tercapai sesuai dengan kriteria keberhasilan yang ditentukan.Berdasarkan hasil pengolahan datadata dan hasil observasi dilakukan analisis dan dapat diketahui bahwa semua tujuan telah tercapai sesuai dengan kriteria keberhasilan yang ditentukan.

\section{Pembahasan}

Penggunaan teknik membaca intensif akan sangat membantu dalam membangkitkan motivasi belajar siswa, ini terbukti dari hasil belajar yang diberikan pada setiap siklusnya mengalami peningkatan di mana pada siklus I nilai rata-rata yang diperoleh siswa adalah
66,09 dan pada siklus II rata-rata nilai yang diperoleh siswa adalah 72,61. Rekapitulasi nilai hasil tes formatif siswa dari kondisi awal, siklus I sampai dengan siklus II dapat dilihat dari tabel di bawah ini.

Tabel 6. Rekapitulasi Nilai Hasil Tes Formatif Temuan Awal, Siklus I dan Siklus II

\begin{tabular}{|c|c|c|c|c|c|c|c|}
\hline \multirow[b]{2}{*}{ No } & \multirow[b]{2}{*}{ Siklus } & \multirow[b]{2}{*}{$\begin{array}{c}\text { Nilai } \\
\text { Rata- } \\
2\end{array}$} & \multicolumn{4}{|c|}{ Ketuntasan } & \multirow[b]{2}{*}{ Ket } \\
\hline & & & $\mathbf{T}$ & $\%$ & B & $\%$ & \\
\hline 1 & Awal & 72,73 & 7 & 21,21 & 26 & 78,79 & \\
\hline 2 & Siklus I & 78,33 & 20 & 60,61 & 13 & 39,39 & \\
\hline 3 & Siklus II & 82,27 & 31 & 93,94 & 2 & 6,06 & \\
\hline
\end{tabular}

Sesuai dengan kriteria keberhasilan yang telah ditetapkan dalam perbaikan pembelajaran bahwa siswa yang dinyatakan tuntas belajar jika mendapat nilai tes formatif sebesar 80 ke atas dan jika $85 \%$ dari siswa telah tuntas belajarnya. Untuk memperjelas kenaikan ketuntasan belajar siswa dan penurunan ketuntasan belajar siswa dapat dilihat pada diagram batang di bawah ini :

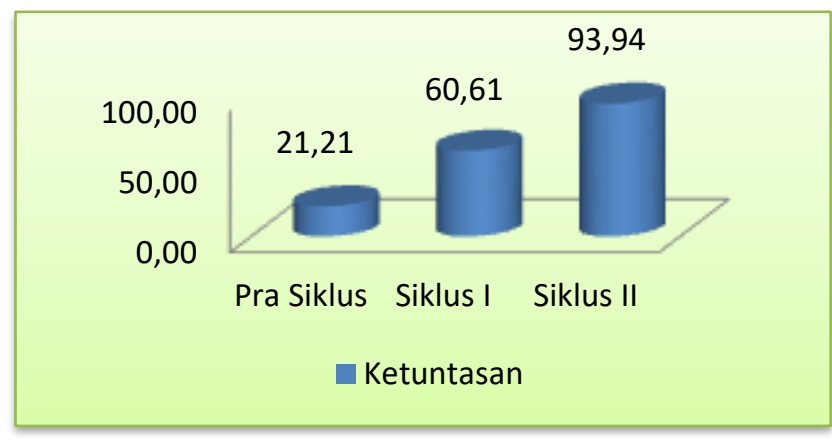

Gambar 1. Grafik Peningkatan Ketuntasan Belajar Siswa pada Kondisi Awal, Siklus I dan II 
Keberhasilan proses perbaikan pembelajaran tidak hanya dilihat dari peningkatan hasil belajar atau nilai tes formatif saja. Motivasi belajar siswa selama proses pembelajaran juga merupakan indikator keberhasilan dalam proses pembelajaran. Data motivasi siswa diperoleh dari lembar observasi yang telah diisi oleh observer selama perbaikan pembelajaran berlangsung. Fokus observasi difokuskan pada aspek-aspek kuatnya kemauan untuk berbuat, jumlah waktu yang disediakan untuk belajar, kerelaan meninggalkan kewajiban atau tugas yang lain, ketekunan dalam mengerjakan tugas, ulet menghadapi kesulitan (tidak lekas putus asa, menunjukkan minat terhadap bermacam- macam masalah orang, lebih senang bekerja mandiri, dapat mempertahankan pendapatnya, cepat bosan pada tugas-tugas rutin (Sardiman, 2001: 81).

Hasil observasi pada pelaksanaan kegiatan perbaikan pembelajaran menunjukkan hasil yang positif, dan dibuktikan dengan adanya peningkatan motivasi siswa pada setiap siklusnya. Secara rinci penjelasan mengenai peningkatan motivasi siswa dalam proses perbaikan pembelajaran sebagaimana tabel di bawah ini :

Tabel 7. Rekapitulasi Peningkatan Motivasi Siswa pada Siklus I dan Siklus II

\begin{tabular}{llllllll}
\hline \multirow{2}{*}{ No } & \multirow{2}{*}{ Siklus } & \multicolumn{4}{c}{ Ketuntasan } & \multirow{2}{*}{$\begin{array}{c}\text { Ket } \\
\text { T }\end{array}$} \\
\cline { 2 - 7 } & Awal & 8 & 24,24 & 1 & Awal & 8 & \\
\hline
\end{tabular}

\begin{tabular}{lllllll}
2 & Siklus I & 21 & 63,64 & 2 & Siklus I & 21 \\
\hline 3 & Siklus II & 31 & 93,94 & 3 & Siklus II & 31 \\
\hline
\end{tabular}

Dari tabel di atas dapat dijelaskan tentang siswa yang tuntas dan belum tuntas dilihat dari motivasi belajarnya, yaitu pada temuan awal, siswa tuntas dilihat dari motivasi belajar sebanyak 8 siswa atau $24,24 \%$ dari 33 siswa, pada siklus I siswa tuntas dilihat dari motivasi belajar sebanyak 21 siswa atau 63,64\% dari 33 siswa, dan pada siklus II tuntas dilihat dari motivasi belajar sebanyak 31 siswa atau $93,94 \%$ dari 33 siswa.

Secara jelas peningkatan motivasi siswa selama proses perbaikan pembelajaran sebagaimana dijelaskan pada gambar di bawah ini :

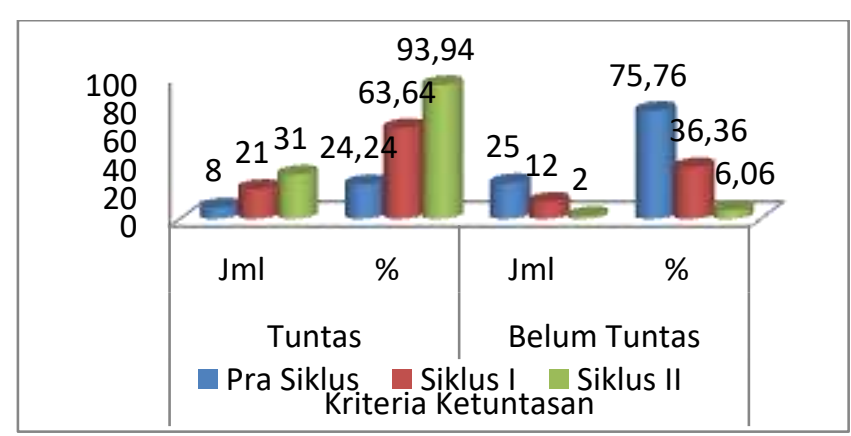

Gambar 2. Grafik Ketuntasan Siswa Berdasarkan Tingkat Motivasi Siswa Pada Siklus I dan II

Dari hasil observasi mengenai motivasi siswa tersebut berdasarkan kriteria keberhasilan perbaikan pembelajaran dapat disimpulkan bahwa proses perbaikan pembelajaran dinyatakan berhasil karena peningkatan motivasi siswa mencapai angka 93,94\% dari $85 \%$ batasan 


\section{Jurnal Serunai Ilmu Pendidikan Vol.5, No.2, Desember 2019 e-ISSN 2621 - 2676}

minimal yang telah ditentukan pada kriteria keberhasilan proses perbaikan pembelajaran.

Atas dasar pertimbangan sebagaimana diurakan di atas, maka peneliti dan observer sepakat memutuskan bahwa kegiatan perbaikan pembelajaran diakhiri pada siklus II. Berdasarkan data-data hasil pelaksanaan perbaikan pembelajaran sebagaimana diuraikan di atas berupa data hasil tes formatif siklus I, tes formatif siklus II dan data hasil observasi siklus I dan II maka dapat disimpulkan bahwa penggunaan teknik membaca intensif dapat meningkatkan hasil belajar dan motivasi siswa pada pembelajaran Bahasa Indonesia kompetensi dasar menentukan kalimat kesimpulan (ide pokok) dari berbagai pola paragraf induksi, deduksi siswa kelas XII IPS-1 SMAN 1 Hinai Kabupaten Langkat Tahun Pelajaran 2018/2019.

\section{KESIMPULAN}

Berdasarkan hasil diskusi, data dan hasil temuan dapat ditarik kesimpulan bahwa : Penggunaan teknik membaca intensif pada pembelajaran Bahasa Indonesia kompetensi dasar menentukan kalimat kesimpulan (ide pokok) dari berbagai pola paragraf induksi, deduksi mampu meningkatkan motivasi dan hasil belajar siswa. Hal ini dikarenakan pembelajaran dilaksanakan dengan kegiatan praktik langsung tidak hanya sebatas teori saja sehingga pemahaman siswa terhadap materi pembelajaran menjadi lebih baik.
Pengaturan kelompok belajar adalah sebagai bagian dari metode untuk meransang siswa dalam suasana kelas yang berbeda, sehingga terjadi pembelajaran yang lebih menarik. Saling berinteraksi saat siswa memaparkan atau hasil kerjanya dalam kompetensi dasar menentukan kalimat kesimpulan (ide pokok) dari berbagai pola paragraf induksi, deduksi yang dibacanya. Hal inilah yang akan membangkitkan motivasi dan hasil belajar siswa dalam pelaksanaan proses pembelajaran.

Kenyataan di atas didukung dengan perolehan nilai yang semakin meningkat pada setiap siklusnya. Nilai rata-rata kelas semakin meningkat dari 72,73 pada studi awal, menjadi 78,33 pada siklus I, dan pada siklus II menjadi 82,27 dengan tingkat ketuntasan belajar dari 7 siswa atau 21,21\% menjadi 20 siswa atau $60,61 \%$ dan 31 siswa atau 93,94\% pada siklus kedua. Adapun peningkatan motivasi belajar juga semakin membaik, pada studi awal sebesar $24,24 \%$ (8 siswa) menjadi 21 siswa $(63,64 \%)$ pada siklus I, dan 93,94\% (31 siswa) pada siklus II.

\section{DAFTAR PUSTAKA}

Arikunto, S. (2007). Dasar-Dasar Evaluasi Pendidikan. Jakarta : Bumi Aksara 
Cahyani, I (2007). Kemampuan Berbahasa Indonesia di Sekolah Dasar. Bandung : UPI Press

Ismoyo. 2008. Aku Bangga Bahasa Indonesia 5. Jakarta : Depdiknas

McCrimmon, J.M, 1972. Writing with A Purpose. Florida: Florida State University.

Mulyasa, E 2006. Menjadi Guru Profesional : Menciptakan Pembelajaran Kreatif dan Menyenangkan. Remaja Rosdakarya. Bandung.

Mulyati, Yeti dkk. (2007). Keterampilan Berbahasa Indonesia SD. Jakarta : Universitas Terbuka.

Natawidjaja, Rochman. (1997). Penelitian Tindakan. Bandung : IKIP

Nur'aini, Umri. 2008. Bahasa Indonesia 5, Jakarta : Depdiknas

Prihatiningsih, Rokhmah. Nim. 2101407020. Peningkatan Keterampilan Membaca Intensif Menemukan Ide Pokok dan Permasalahan Dalam Artikel Dengan Pada Siswa Kelas V Sekolah Dasar Nasional Kabupaten Pati Tahun Ajaran 2010/2011. Program Pendidikan Bahasa, Sastra Indonesia, dan Daerah (Pendidikan Bahasa dan Sastra Indonesia), Fakultas Bahasa dan Sastra Universitas Negeri Semarang.

Rahim, Farida. (2008). Pengajaran Membaca di Sekolah Dasar. Jakarta : Bumi Aksara.

Sugiyono. (2009). Metode Penelitian Pendidikan. Bandung : Alfabeta
Resmini, Novi dkk. (2009). Pembinaan dan Pengembangan Pembelajaran Bahasa dan Sastra Indonesia. Bandung : UPI Press.

Romiyatun, I. (2007). Aku Bangga Bahasa Indonesia Sekolah Dasar Kelas 5. Jakarta : Pusat Perbukuan Depdiknas.

Santosa, Puji. 2003. Materi dan Pembelajaran Bahasa Indonesia SD. Jakarta : Universitas Terbuka.

Saylor. 1981. Psychology Today (An introduction). California: Del Mar, Inc.

Semiawan, Conny. dkk. (1992). Pendekatan Keterampilan Proses : Bagaimana Mengaktifkan Siswa dalam Belajar. Jakarta: Gramedia Widiasarana Indonesia.

Slavin, RE.(1994). Educational Psychology : Theory and Practice. Masschusetts: Allyn and Bacon Publisher.

Suciati, 2003. Belajar dan Pembelajaran 2. Pusat Penerbitan Universitas Terbuka. 2003.

Sugiyono. (2009). Metode Penelitian Pendidikan: Pendekatan Kuantitatif, Kualitatif, dan $R \quad \& D$. Bandung : Alfabeta.

Suherman \& Winataputra. (1992). Strategi Belajar Mengajar. Jakarta: Depdikbud.

Sunendar, Tatang. (2009). Penelitian Tindakan Kelas. Bandung: LPMP Jawa Barat.

Syamsudin, Abin. Nandang Budiman. Profesi Keguruan 2. Pusat Penerbitan Universitas Terbuka. 2003. 
Tarigan, HG (2008). Membaca Sebagai Suatu Keterampilan Berbahasa. Bandung : Angkasa.

Wardani, I.G.A.K, Julaeha. S, dan Marsinah Ng. 2005. Pemantapan Kemampuan Profesional (Panduan). Pusat Penerbitan Universitas Terbuka. 2005.

Wardhani, Maylana Khusna. A 310070024. Upaya Meningkatkan Kemampuan Menemukan Kalimat Utama Pada Tiap
Paragraf Melalui Membaca Intensif Pada Peserta Didik Kelas IV SDN 03 Tugu Kecamatan Jumantono Tahun Ajaran 2010/2011. Jurusan Pendidikan Bahasa, Sastra Indonesia dan Daerah. Fakultas Keguruan dan Ilmu Pendidikan. Universitas Muhammadiyah Surakarta

Winataputra, Udins. 1997. Strategi Belajar Mengajar. Departemen Pendidikan dan Kebudayaan. Proyek Peningkatan Mutu Guru Kelas SD Setara D.II. jakarta. 1997. 